Nhu cầu của người bênh UTV điều trị hóa chất là rất lớn, đặc biệt về tâm lý và tình cảm. Hoạt động của điều dưỡng tại Khoa Điều trị theo yêu cầu - Bênh viên $K$ được người bệnh ghi nhận và đánh giá rất cao. Điều dưỡng cần chú ý tới nhu câu thể chất của người bệnh vì có sự liên quan giữa giai đoạn bệnh và nhu cầu về thể chất. Các nghiên cứu sâu hơn với cõ̃ mẫu nhiều hơn là cần thiết để làm sáng tỏ hơn các nhu cầu thực tế của người bệnh ung thứ.

\section{TÀI LIÊU THAM KHẢO}

1. Trân Văn Thuấn (2019). Điều trị nọi khoa Bênhh ung thư vú. Nhà xuất bản y hoc, 13-34.

2. GLOBOCAN (2018). Breast Cancer - Estimated Incidence, mortality and prevalence Worldwide.
3. Chan S, Fredrichs K, Noel D, et al (1999). Prospetive randomized trial of docetaxel versus doxorubicin in patients with metastatic breast cancer. J Oncol; 2341-54.

4. Bô Y tế (2011). Thông tư số 07/2011/TTBY̛Tngày 26/01/2011 Hướng dẫn công tác điều dưỡng về chăm sóc người bệnh trong bệnh viện.

5. Đào Văn Tú, Trân Văn Thuấn, Trân Đ̣ăng Khoa, Ngô Quốc Duy (2015). Sư thay đổi đăc điểm thu thể nôi tiết, thu thể phát triển biểu mô và ki67 ở bệnh nhân ung thư vú trước và sau hóa tri. Tap chí Ý hoc Viêt Nam, số 1, 83-87.

6. Bùi Thi Bích Ngà (2011). Thực trạng công tác chăm sóc của điểu dưỡng qua nhân xét của ngườ bệnh nôi trú tai bênh viện $Y$ học cổ truyền Trung ương năm 2011, Luận văn thạc sỹ quản lý bệnh viên, Trường Đai hợ Y tế Công công.

7. Trân Văn Thuấn và Lê Văn Quảng (2019) Hướng dẫn Chăm sóc người bệnh ung thư, Nhà xuất bản $Y$ học.

\title{
KẾT QUẢ CA GHÉP HAI PHỔI ĐẦU TIÊN TỪ NGƯỜI CHO ĐA TẠNG CHẾT NÃO TẠI BỆNH VIỆN HỮU NGHI VIỆT ĐỨC
}

\author{
Nguyễn Hữu Ước*, Phạm Tiến Quân*, Vũ Văn Thời*, Phạm Hữu Lu*, \\ Tạ Thị Huyền Trang*, Nguyễn Kim Dần*, Nguyễn Quốc Kính*, \\ Trịnh Kế Điệp*, Dương Hoàng Long*, Nguyễn Việt Anh*, \\ Phùng Duy Hồng Sơn*, Nguyễn Thị Thu Hà*, Nguyễn Xuân Vinh*, \\ Trần Đăng Thanh*, Phạm Gia Anh*, Trịnh Hồng Sơn*, Trần Bình Giang* \\ Nguyễn Thanh Hồi**, Vũ Văn Giáp***, Ngô Quý Châu***
}

TÓM TẮT

Mục tiêu: Thông báo kết quả ca ghép hai phổi từ người cho đa tạng chết não đâu tiên tại bệnh viện Hữu Nghi Viêt Đức. Đối tượng và phương pháp: Mô tả trường hợp lâm sàng ca ghép hai phổi được thực hiên vào ngày 12 tháng 12 năm 2018, và theo dõi đển tháng 8 năm 2020. Kết quả: Người hiến đa tạng là nam, 43 tuổi, người nhận là nam, 17 tuổi. Phù hợp miễn dịch người cho - người nhận ở mức tốt. Thương tổn phổi của người nhân là bênh mô bào phối (Langerhans) giai đoạn cuối. Ca mổ ghép phổi kéo dài 15 giờ, dựa trên các qui trình đã xây dưng chi tiết trước mổ. Hậu phẫu rất phức tạp, kéo dài 10 tháng sau mổ, với 2 tháng đâu khá thuận lợi, sau đó xuất hiện nhiều biến chứng muộn. Hiện bệnh nhân còn sống sau mổ 20 tháng, với các di chứng hẹp vừa đường hô hấp mạn tính. Kết luận: Ghép phổi là một kỹ thuật rất phức tạp, tổ chức thực hiện khó khăn.

*Bệnh viện Hữu nghị Việt Đức

**Đại học Y Dước Hải Phòng

***Bênh viên Bach Mai

Chịu trách nhiệm chính: Nguyễn Hữu Ước

Email: uocdhyhn101@yahoo.com.vn

Ngày nhận bài: 28.10 .2020

Ngày phản biện khoa học: 27.11.2020

Ngày duyệt bài: 11.12 .2020 Đức.

Tư khóa: ghép phổi, ghép hai phổi, chết não, Việt

\section{SUMMARY}

\section{RESULT OF DOUBLE LUNG}

TRANSPLANTATION FROM BRAIN-DEAD DONOR AT VIET DUC UNIVERSITY

HOSPITAL: REPORT OF A FIRST CASE

Purpose: Evoluate result of the first lung transplant from multi-organs brain-dead donor at Viet Duc University hospital. Methods: Descriptive study a clinical case of double-lung transplantation on December 12, 2018, and follow-up until August 2020. Result: multi-organ donor was male gender - 43 years old; The recipient was male - 17 years old. Donor - recipient immunal consistent was good. The recipient's lung lesion was terminal lung Langerhans disease. The 15-hour lung transplant, based on detailed pre-surgical protocols. Postoperative was very complicated, lasting 10 months after surgery, with the first 2 months quite favorable, then later appeared many late complications. Currently the patient survives 20 months after surgery, with sequelae of middle chronic bronchial stenosis. Conclusion: Lung transplantation is a very complicated procedure and organization.

Key words: lung transplant, double lung transplant, brain death, Viet Duc. 


\section{I. ĐĂT VẤN ĐỀ}

Trong hơn 10 năm qua, ghép tạng được đặc biệt quan tâm ở Việt Nam. Bệnh viện Hữu nghi Việt Đức (BV Việt Đức) là đợn vị đầu đàn về ghép tạng từ người cho đa tạng chết não. Riêng về ghép phổi, đã có những thành công bước đầu tại Học viện Quân y, bệnh viện 108, bệnh viện trung ương Huế, nhưng vẫn trong giai đoạn nghiên cứu [3-4]. Ghép phổi được chỉ đinh cho những bênh nhân bi bênh phổi mãn tính giai đoạn cuối khi các biện pháp điều trị khác không có hiệu quả, như: bệnh phổi tắc nghẽn mạn tính, xơ phổi nguyên phát, xớ nang phổi, tăng áp lực động mạch phổi.

Nhìn chung, ghép phổi phức tạp hơn các tạng khác cả về tổ chức thực hiện lần kỹ thuật lấy ghép tạng. Có nhiều loại kỹ thuật ghép phổi khác nhau nhưng kỹ thuật ghép 2 phổi cho kết quả tốt nhất và được dùng nhiêu nhất [6], [7-8]. Trên thế giới, ca ghép phổi đầu tiên trên người được thực hiện bởi James D Hardy (1963). Theo báo cáo của tổ chức quốc tế về ghép tim phổi (ISHLT), cho tới 2017, đã có gần 30.000 ca được ghép với chất lượng cuộc sống và chức năng phổi có cải thiện rất rõ rệt. Do vậy, số lượng ghép phổi tăng rất nhanh trong vài năm gần đây [7].

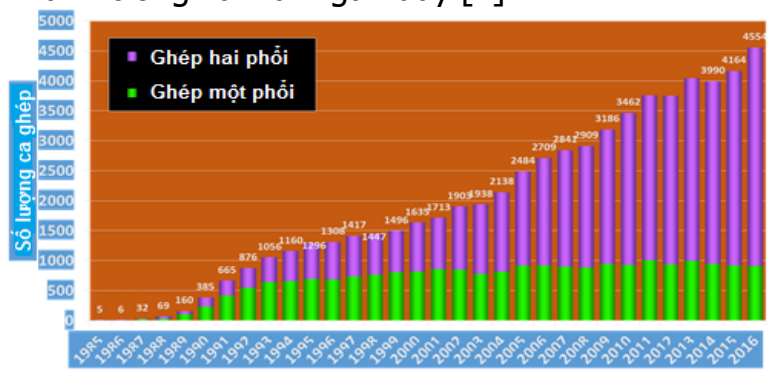

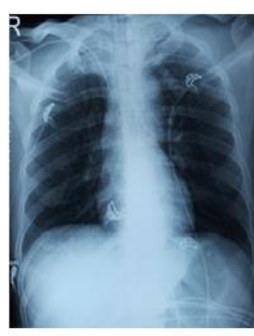

Hiến

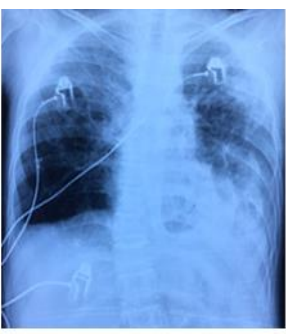

Nhận

Hình 1: Số Iượng kỹ thuật ghép 1 phổi và ghép 2 phổi hàng năm (ISHLT) [7]

Ngày 12/12/2018, BV Việt Đức đã thực hiện thành công ca ghép hai phổi từ người cho chết não đầu tiên. Báo cáo này nhằm trình bày một phần kết quả chính thu được từ quá trình thực hiện đề tài.

\section{II. ĐỐI TƯƠ'NG VÀ PHƯƠNG PHÁP NGHIÊN CỨU}

Nghiên cứu mô tả, theo dõi dọc trường hợp bênh nhân đầu tiên được ghép hai phổi từ người cho chết não tại BV Việt Đức

\section{KẾT QUẢ NGHIÊN CỨU VÀ BÀN LUÂ̂N}

\section{1. Đặc điểm trước phẫu thuật}

3.1.1. Người hiến $(\mathrm{NH})$ đa tạng chết não (ĐTCN) là BN nam, 43 tuổi, ở Ninh Bình, bị võ dị dạng mạch não. Thời gian thở máy là 6 ngày, không có chống chỉ định hiến đa tạng và phổi. Trong điêu kiện ở Việt Nam, nên chọn NH phổi có thời gian thở máy dưới 5 ngày, để hạn chế nhiễm khuẩn. Quan điểm chung trên thế giới đa số cũng chọn trong 10 ngày [4].

Trên $X$ quang ngực và MSCT ngực tình trạng mô phổi rất tốt, không thấy thuyên tắc động mạch phổi (TTÐMP) (Hình 2). Do tính chất khan hiểm của tạng hiến, nên cho phép lấy phổi bị chấn thương - đụng dập nhẹ, mặt khác TTĐMP có nguy cơ xuất hiện ở bệnh nhân nằm viện bất động lâu ngày, ảnh hưởng nặng nề đến kết quả ghép phổi do đó cần chụp MSCT phổi NH thường quy. Xét nghiệm khí máu trong giới hạn bình thường, trên siêu âm tim áp lực động mạch phổi (ALĐMP) 28mmHg; nếu ALEMP trên 35$40 \mathrm{mmHg}$ thì phải xem xét kỹ các yếu tố tiên lượng xấu, như: phù phổi, bệnh tim, thuyên tắc động mạch phổi, suy tim phải [6].

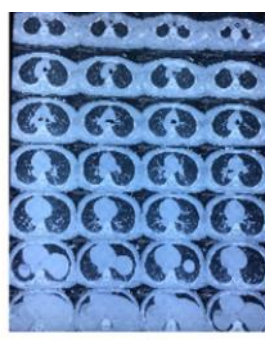

Hiến

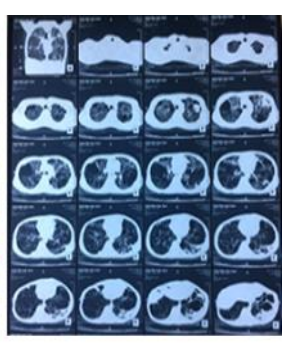

Nhận

Hình 2. X quang và MSCT ngực (64 dãy) người hiến đa tạng và nhận phổi.

Nội soi khí phế quản (NSKPQ) không có tổn thương thực thể, lượng đờm không nhiều. Kết quả cấy đờm âm tính sau 24 giờ, đây cũng là các tiêu chí rất quan trọng, tốt nhất là kết quả kết quả nuôi cấy sau 48-72 giờ; tuy nhiên do tính chất khẩn trương của ghép từ $\mathrm{NH}$, nên không ca bệnh này không thể chờ được. Để đảm bảo chất lượng phổi hiến, cần phải dựa thêm vào tình trạng nhiễm trùng của $\mathrm{BN}$, kết quả cấy đờm trước đó (nếu có), và quan trọng nhất là đánh giá trong khi NSKPQ [9]. 
Thời gian hồi sức NH trước ghép kéo dài 40 giờ. Thời gian từ khi có xác định chắc chắn chết não đến khi lấy tạng là 8 giờ. Trong hồi sức $\mathrm{NH}$ ĐTCN, việc xác định có ghép phổi hay không là rất quan trọng để định hướng "hồi sức theo đích". Nếu có lấy phổi ghép, thì cố gắng bảo vê phổi không bị phù, xuất tiết khoảng kẽ (để phổi "khô"). Thời gian chết não càng dài thì càng có điều kiện bảo vệ phổi, nhưng quá dài thì lại tăng nguy cớ nhiễm trùng và suy đa tạng (thận); do vậy trên thế giới, khoảng thời gian điều trị phổi ghép phù hợp nhất là 24-48 giờ. Các kỹ thuật chăm sóc đường hô hấp (hút, soi...) cũng phải hạn chế gây sang chấn nội mạc phế quản, và đưa dị vật bẩn từ ngoài vào đường hô hấp kết hợp với kháng sinh toàn thân liều cao, phổ rộng, phối hợp $\geq 2$ thuốc [7]. Thông thường, sau khi chẩn đoán xác định chết não thì nên mổ lấy đa tang càng sớm càng tốt, tránh để suy chức năng các tạng hiến. Ở trường hợp này (8 giờ) là hợp lý, vì cần thời gian chuẩn bị các BN nhận tạng, nhất là ca ghép phổi đầu tiên. Đối với các trường hợp tương tự tại BV Việt Đức, thời gian này dao động từ khoảng 1 - 12 giờ [5].

3.1.2. Ngưới nhận phổi là $B N$ nam, 17 tuổi, quê quán Hải Dương mắc giãn phế nang do bệnh mô bào phổi (Langerhans) giai đoạn cuối. Bn đã mổ bên phổi phải và gây dính màng phổi bên trái do vỡ kén khí tái diễn, nhiều lần hóa trị và điều trị nhiễm trùng phổi tại $B V$ Nhi Trung ương và $B V$ Bạch Mai, mố lấy sỏi thận phải (2016), suy chức nằng gan sau truyền hóa chất, sỏi nhỏ trong gan. Cách 1 tháng, BN được điêuu trị nội tối ưu tai BV Bach Mai, tình trang còn rất nặng, nguy cơ tử vong cao trong vài tháng nếu không ghép phổi. BN được chuyển đến BV Việt Đức trước ghép gần 2 ngày, trong tình trạng suy hô hấp nặng, nằm tại giường, thở ô xy liên tục 3 lit́/phút, $\mathrm{SpO}_{2} \approx 96-99 \%$, suy dinh dương nặng $(B M I \approx 13,3)$, chu vi lồng ngực $75 \mathrm{~cm}$; nhóm máu $\mathrm{B}-\mathrm{Rh}(+)$; lồng ngực gồ cao, gõ vang, có ít ran. Các cơ quan khác được thám sát không thây bệnh lý chống chỉ định ghép phổi.

Kết quả xét nghiệm huyết học hầu như trong giới hạn bình thường. Xét nghiệm sinh hóa thây có suy dinh dưỡng và suy nhẹ chức năng gan, với albumin thấp $(30,4 \mathrm{~g} / \mathrm{l})$, GOT/GPT tăng $(142 / 79 \mathrm{U} / \mathrm{L})$, bilirubin tăng (TP/TT $\approx 53 / 26)$. Biểu hiên nhiễm trùng được kiểm soát với procalcitonin không tăng cao $(0,123 \mathrm{ng} / \mathrm{ml})$, CRP tăng nhẹ $(43 \mathrm{mg} / \mathrm{l})$. Siêu âm gan mật thấy nhu mô rải rác vài nốt vôi hóa và u máu nhỏ, vài sỏi nhỏ ở đường mật trong gan, ống mật chủ xẹp không sỏi và tắc nghẽn, không có chỉ định can thiệp ngoại khoa. Thăm dò chức năng tim tốt, ALĐMP tăng nhẹ $(30 \mathrm{mmHg})$. Trong một số bệnh lý phổi lâu ngày, ALĐMP thường tăng cao, nhưng chỉ được tới $2 / 3$ huyết áp $(\leq 75 \mathrm{mmHg})$, còn nếu hơn nữa - phải xét ghép cả phổi và tim.

$X$ quang ngực và MSCT thấy toàn bộ phổi đã bị tiêu hủy thành các nang - kén khí, không còn hoạt động chức năng (Hình 2). Kích thước các phế quản gốc tương đương với người hiến. Đo chức năng hô hấp thấy rối loạn thông khí hạn chế rất nặng: FVC (L-\%) $\approx 0,44$ (L-13\%); FEV1(L-\%) $\approx 0,41$ (L-14\%); FEV1/FVC $\approx 93 \%$. Xét nghiệm khí máu động mạch thấy trao đổi phổi rất kém: $\mathrm{pH}(7,5) ; \mathrm{PaCO}_{2}(35) ; \mathrm{PaO}_{2}(78)$; $\mathrm{HCO}_{3}(27,3) ; \mathrm{P} / \mathrm{F}(200)$. Các thăm dò khác không làm được do tình trạng $B N$ quá nặng (test đi bộ 6 phút, xạ hình phổi).

Xét nghiệm định tính các virus đều âm tính, và không có nguy cơ lây nhiễm chéo người cho người nhận. Người nhận đang nhiễm virus không phải là chống chỉ định tuyệt đối, song cũng làm tăng nguy cơ rủi ro của phẫu thuật ghép tạng.

3.1.3. Hòa hợp miễn dịch người cho - người nhận phổi

Bảng 1. Mức độ hòa hợp các chỉ số miễn dịch của người cho và nhận phổi

\begin{tabular}{|c|c|c|}
\hline Chỉ số & $\begin{array}{l}\text { Người } \\
\text { cho }\end{array}$ & $\begin{array}{l}\text { Người } \\
\text { nhận }\end{array}$ \\
\hline HLA LỚP I & $\begin{array}{l}* 02 ; \\
\text { A*24; } \\
B^{*} 54 ; \\
\text { B*46 }\end{array}$ & $\begin{array}{l}\text { A*01; } \\
\text { A*24; } \\
\text { B*40; } \\
\text { B*46 }\end{array}$ \\
\hline HLA LỚP II & $\begin{array}{l}\text { DRB*12; } \\
\text { DRB*14 }\end{array}$ & $\begin{array}{l}\text { DRB1*08; } \\
\text { DRB1*09 }\end{array}$ \\
\hline $\begin{array}{c}\text { Kháng thế kháng } \\
\text { HLA lớp I, II }\end{array}$ & Âm tính & Âm tính \\
\hline
\end{tabular}

Do vần tuân thủ theo nguyên tắc truyền máu, nên sự khác biệt của nhóm máu người cho $(O)$ và người nhận (B) thì không quan trọng trong ghép tạng. Cả người cho và nhận đều không có kháng thể kháng HLA. Hòa hợp HLA ở mức cao (2/6) trong ghép tạng không cùng huyết thống [5].

3.1.4. Chi định ghép phổi Về mặt bệnh học, người nhận mắc bệnh phổi thuộc nhóm $\mathrm{D}$ - bệnh phổi hạn chế giai đoạn cuối, tuy là bệnh ít gặp, nhưng chỉ định ghép phổi rất rõ ràng $[1],[2]$. Về chống chỉ định, có một chống chỉ định tương đối - là suy dinh dưỡng nặng. NH phổi đáp ứng đầy đủ các tiêu chí hiến đa tạng - trong đó có phổi.

\section{2. Đặc điểm trong mổ ghép phổi}



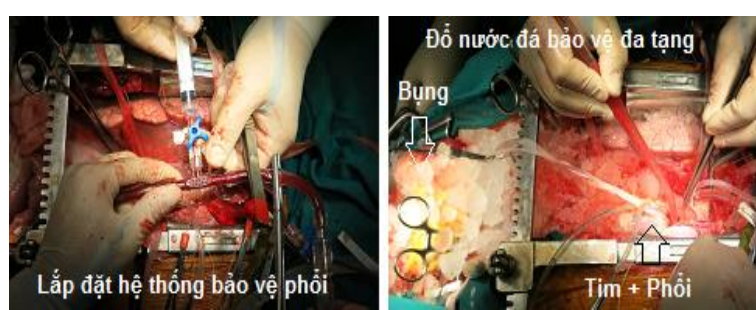

Hình 3. Bảo vệ tim, phổi và đa tạng trước khi lấy

3.2.1. Trong mố lấy đa tạng (Hình 3-4). Lấy đa tang theo các qui trình đã xây dựng với thuốc chính là Perfadex (các tạng khác là Custodiol). Tổng thời gian mổ lấy đa tạng là 6 giờ 30 phút, trong đó mổ lấy hai phổi kéo dài 2 giờ 10 phút.
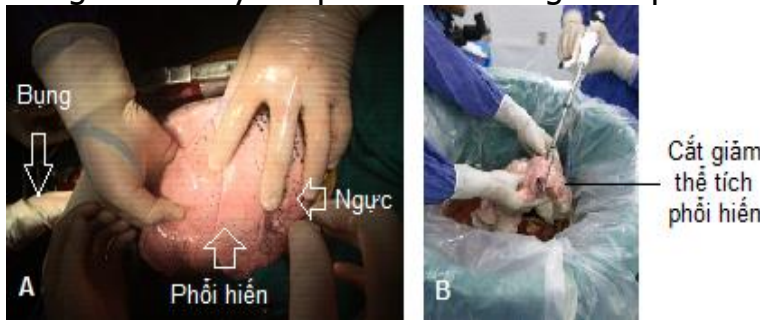

Hình 4. Lấy phổi ghép ra khỏi lồng ngực (A) và chuẩn bi phổi trước ghép (B)

3.2.2. Trong mổ ghép phổi. Tống thời gian ghép phổi kéo dài hơn 15 giờ, gồm các thì chính nhu' sau:

a) Thì gây mê + gõ dính phổi $\left(5 h 30^{\prime}\right)$ : Khởi mê sau khi mở ngực NH $\rightarrow$ Chuẩn bị tư thế, hệ thống $\mathrm{ECMO}$, vô trùng vùng mổ $\rightarrow$ Mở ngực theo đường Clamshell (Hình 5$) \rightarrow$ Bôc lộ và gỡ dính phổi phải + chạy ECMO (V-A) hỗ trợ $\rightarrow$ Cắt phổi phải, chuẩn bị cuống phổi và khoang ngực phải để ghép. Tổng số máu mất $400 \mathrm{ml}$, máu truyền vào 2 đơn vị; chưa cần trợ tim; nước tiểu $\approx 100 \mathrm{ml} / \mathrm{h}$; dùng 2 kháng sinh liêu cao phổ rộng; khí máu động - tĩnh mạch ổn định, kể cả sau khi chay ECMO.

b) Thì chuẩn bị phổi ghép tại phòng mổ ghép phổi $\left(1 \mathrm{~h} 00^{\prime}\right)$ : Lấy phổi ghép khỏi thùng bảo quản $\rightarrow$ Rửa - bảo quản (Perfadex $10^{\circ} \mathrm{C}$ ) theo qui trình $\rightarrow$ Chuẩn bị phổi ghép (sửa các miệng nối, cắt giảm thể tích thừa). Làm các xét nghiệm vi sinh, tế bào dịch ngâm và rửa phổi. Quá trình rửa - bảo quản phổi theo qui trình. Sau khi chia tách và chuẩn bị phổi ghép, thấy kích thước phổi hiến > lồng ngực người nhận, nên đã cắt bỏ thùy giữa phổi phải (Hình 4).

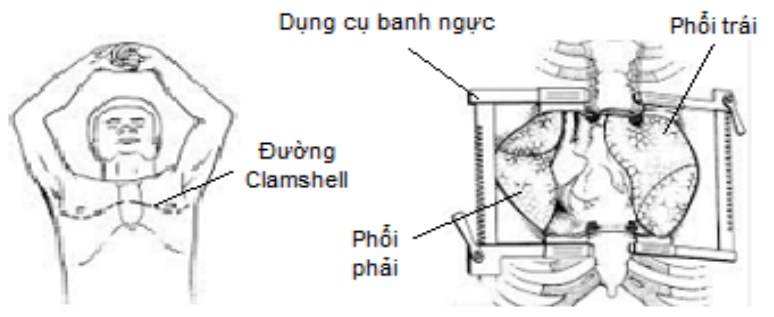

Hình 5. Tư thế $B N$ và đường mổ Clamshell

c) Thì ghép phổi: Các thì mổ tuân thủ chặt chẽ qui trình (Hình 6.A), đảm bảo chắc chắn các miệng nối (động mạch, tĩnh mạch, phế quản). Nhờ có ECMO hổ trợ nên có thể đè ép, bộc lộ rõ cuống phổi để khâu nối $\rightarrow$ Phổi được tái thông khí, test đánh giá chất lượng phổi ghép (khí máu, soi phế quản).

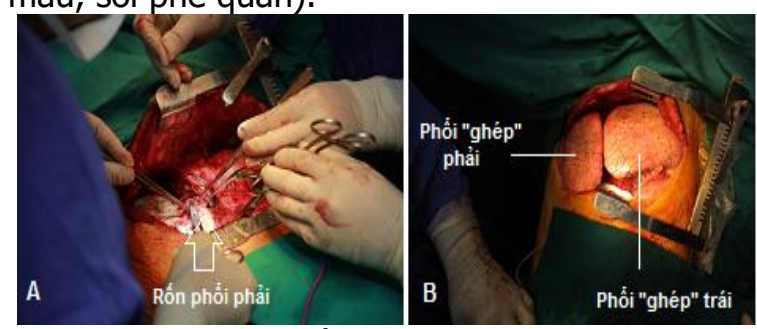

Hình 6. Ghép phổi phải (A) và tái thông khí 2 phôi sau ghép (B)

d) Kiểm tra phổi ghép (1h00'): Sau khi ghép, cả hai phổi được thông khí trở lại (Hình 6.B) + giảm lưu lượng ECMO xuống $<1 / 2, \mathrm{FiO}_{2}$ điều chỉnh như thở máy bình thường $\rightarrow$ Đánh giá hoạt động chức năng phổi theo qui trình: khí máu động mạch; chức năng tim, miệng nối động - tĩnh mạch phổi, ALĐMP bằng siêu âm Doppler mâu qua thực quản; NSPQ đánh giá các miệng nối phế quản $\rightarrow$ Tất cả các test kiểm tra đều có kết quả tốt: khí máu tốt; các miệng nối thông, áp lực động mạch phổi $<25 \mathrm{mmHg}$.

e) Kểt thúc ca mổ $\left(1 \mathrm{~h} 00^{\prime}\right)$ : Cầm máu kỹ và rửa sạch khoang màng phổi bằng dung dịch Betadin loãng, mỗi khoang màng phổi đặt 02 ống dẫn lưu (18 và $28 \mathrm{Fr}$ ) máu và khí $\rightarrow$ Cầm máu kỹ thành ngực $\rightarrow$ không đóng ngực (Hình 7) $\rightarrow$ Duy trì hệ thống ECMO tiếp tục sau mổ. Chuyển $B N$ về phòng hồi sức sau ghép phổi.

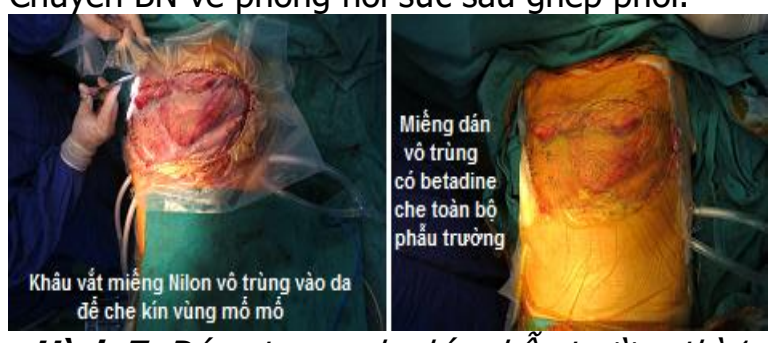

Hình 7. Đóng tạm - che kín phẫu trường thi 1 
Quá trình kết thúc ca mổ ghép phổi này có một số đặc điểm riêng - phù hợp với ca ghép phổi đầu tiên trong điều kiện BV Việt Đức, cụ thể như sau:

- Cầm máu thật kỹ trường mổ, hạn chế phải mổ lại -> giảm nguy cơ nhiễm trùng màng phổi biến chứng rất nặng sau ghép phổi [4].

- Duy trì ECMO trong 2-3ngày sau mổ hỗ trợ giúp cho phổi được "nghỉ ngơi" một phần trong một số ngày đầu tiên, phòng biến chứng tim - phổi có thể xuất hiện và đe dọa tính mạng BN [6].

- Để hở vểt mổ ngực: theo các khuyến cáo về ghép phổi, thì thể tích phổi hiến luôn lớn hơn lồng ngực người nhận trong đa số các trường hợp do nhiêu yếu tổ khác nhau (phù, nhu câu chức năng). Nếu khép kín khoang ngực ngay có thể gây tăng áp lực đè vào nhu mô phổi, dẫn đến thiếu máu nuôi dưỡng phổi, xẹp phổi. Nhiều khuyên cáo cho là sau ghép $2-3$ ngày là phổi ghép hết phù, tự co hồi lại phù hợp với kích thước lồng ngực người nhận, lúc đó sẽ tiến hành đóng ngực thì hai.

- Mở khí quản chủ động. Ở một số trung tâm ghép phổi [6], mở khí quản chủ động vẫn được coi là một giải pháp điêu trị cho $>70 \%$ số ca ghép phổi. Quan điểm của chúng tôi là không cần mở khí quản ngay trong khi ghép phổi để giảm nguy cơ nhiễm trùng, chảy máu - mà nên làm đồng thì với đóng vết mổ thì 2 , tức là vào ngày thứ 3 sau ghép.

\section{3. Đặc điểm hậu phẫu và điêu trị -} theo dõi sau ghép phổi

3.3.1. Diễn biến sau ghép phổi tới khi ra viện. Hậu phẫu 03 ngày đâuu có huyết động ổn định, trao đổi phổi tốt, siêu âm tim co bóp tốt, áp lực động mạch phổi không cao, NSKPQ miệng nối kín, lòng phế quản hồng và sạch. ECMO giảm dần và gần như ngừng. Không chảy máu vùng mổ. Các xét nghiệm máu và nước tiểu trong giới hạn ổn định. $X$ quang phổi khá tốt. Nhu mô phổi co hồi vừa đủ với lî̀ng ngực người nhận. $B N$ được đóng kín vết mổ thì 2; mở khí quản; rút hệ thống ECMO tại phòng mổ ngày thứ 3 .

Diễn biến 2 tháng đầu thuận lợi, BN có thể dậy đi lại, tự thở qua mở khí quản, ăn uống khá, hết suy thận, suy gan giảm nhiều - giảm lọc máu.

Tháng thứ $3-5$ : bắt đầu xuất hiện các biến chứng liên quan đến hẹp miệng nối phế quản và phản ứng hẹp phế quản phổi ghép do xơ hóa (fibrosis), nhuyến phế quản (malacia), u hạt (granuloma), được điều trị tích cực bằng các can thiệp đường hô hấp - như: nong bóng, nội soi ống cứng đặt stent phế quản gốc hai bên, đốt điện u hạt mỗi 2 tuần. Tiếp tục điều trị suy gan (bilirubin > 300 nếu không lọc huyết tương 1 lần/1 tuần), lý liệu pháp hô hấp và nuôi dưỡng đường tĩnh mạch hố trợ. Do bệnh kéo dài nhiều năm và suy kiệt nặng, nên hệ tiêu hóa của $B N$ có vấn đề trong việc tiêu hóa và hấp thụ thức ăn qua đường miệng.

Từ tháng thứ 6 đến khi ra viện (ngày 18/10/2019): có tiến triển tốt hơn, lấy bỏ stent phế quản hai bên, song biến chứng hẹp phế quản do tăng sinh u hat vẫn tiến triển, phải can thiệp nong bóng và đốt $u$ hạt thêm 8 lần nữa, cuổi cùng phải đặt stent loại cho mạch máu có vỏ bọc hố trợ. Hết tình trạng suy gan, nuôi dưỡng hoàn toàn qua đường miệng, thay ống mở khí quản bằng dụng cụ chữ "T" và cho ra viện. Sau đó, BN tái khám mỗi 3-4 tuần/lần, kết quả: hệ tiêu hóa hoạt động tốt, không tái suy gan - thận, không có dấu hiệu thải ghép, nồng độ thuốc ức chế miễn dịch ổn định; nhưng u hạt và xớ hóa vẫn tái phát với mức độ chậm hơn, nên phải duy trì mở khí quản và bóp bóng cách quãng.

3.3.2. Những bài học rút ra từ chăm sóc hậu phẫu: Toàn trạng suy kiệt, suy tạng mức độ nhẹ - vừa, tuy không phải là một chống chỉ định tuyệt đối, song cần rất thận trọng khi chỉ định ghép phổi, vì sẽ yêu tố tiên lượng xấu sau ghép. Nuôi dưỡng tĩnh mạch dài ngày, lý liệu pháp hô hấp, và lọc máu - lọc huyết tương là những giải pháp cần chuẩn bị kỹ khi chăm sóc các $B N$ này [3].

Lý liệu pháp hô hấp đóng vai trò quan trọng sau ghép phổi (Hình 8), vì 2 lý do chính: (1) tình trạng suy yếu cơ hô hấp ở BN chờ ghép; (2) phổi ghép từ người hiến sẽ mất các phản xạ thân kinh chủ động để đào thải các dị vật trong lòng phế quản. Biện pháp này phải duy trì kéo dài trong nhiêu tháng, năm sau ghép, với rất nhiêu các biện pháp, kỹ thuật khác nhau [4],[6].

Các biến chứng hẹp đường thớ tiến triển sau ghép phổi là nguyển nhân quan trọng nhất ( $>50 \%)$ dẫn đến tử vong sau ghép phổi 5 năm. Tuy nhiên, việc các căn nguyên (xơ hóa, nhuyễn, u hạt) đồng thời xuất hiện ở cùng một $B N$ như trường hợp này là hiện tượng ít gặp. Việc chuẩn bị mọi phương tiện, nhân lực, vật tư cần thiết để xử trí các biến chứng này là cần thiết khi triển khai ghép phổi (nội soi ống cứng, stent phế quản, bóng nong, đốt cắt $u$ đường thở ...). 


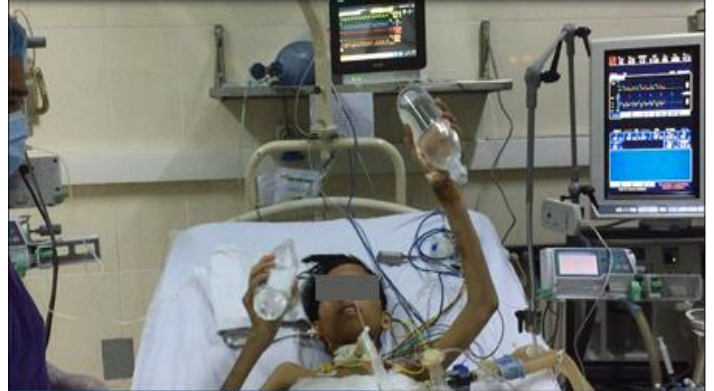

Hình 8. Lý liệu pháp hô hấp cho bệnh nhân sau ghép phổ

3.5. Bàn luận về bệnh Langerhans và ghép phổi [1], [2].

Bệnh mô bào Langerhans là 1 rối loạn khá thường gặp trong bệnh mô bào. Bệnh hay xuất hiện ở trẻ em 1-3 tuổi, có nguồn gốc từ các tế bào Langerhans ở tủy xương. Tổn thương thường gặp ở xương (77\%), da (33\%); ít gặp hơn ở: tủy xương, gan, lách, hạch, phổi (10\%), hệ thần kinh, tuyến yên.

Bệnh mô bào chiếm tỷ lệ ít trong ghép phổi, 10- 20\% tái phát bệnh sau ghép, phụ thuộc các tổn thương ở cơ quan khác và tái nghiện thuốc lá. Một nghiên cứu tại Pháp năm 2006 về ghép phổi cho bệnh nhân Langerhans: tỷ lệ sống sót sau 1 năm $76 \%$, 2 năm là $63 \%, 5$ năm là $57 \%$, 10 năm là $53 \%$; tỷ lệ tái phát bệnh $8 \mathrm{ca}(20,5 \%)$ nhưng không ảnh hưởng đến tỷ lệ sống sót; yếu tố nguy cơ tái phát bệnh liên quan đến tổn thương ngoài phổi mắc trước đó; tăng áp lực động mạch phổi nặng là đặc trưng của bệnh mô bào giai đoạn cuối". Kết luậ̣n của nghiên cứu cho thây dù tỷ lệ tái phát còn cao (20\%) nhưng ghép phổi vẫn là lựa chọn cho bệnh mô bào giai đoạn cuối.

Một số yếu tố tiên lượng tồi trong ghép phổi do bệnh mô bào là: tuổi cao, bệnh đa cơ quan, thời gian diễn biến bệnh dài, thể trạng kém, tổn thương mô bào kích thước lớn + hình tố ong nhiều, giảm dung tích phổi, giảm nặng chức năng hô hấp, điều trị miển dịch kéo dài và tăng áp lực động mạch phổi.

\section{KẾT LUÂN}

Ghép hai phổi từ người cho đa tạng chết não là một thách thức trong ngành ghép tạng, cả về tính tổ chức, độ khó kỹ thuật và sự phức tạp trong chăm sóc sau mổ. Để thực hiện thành công ghép phổi, đòi hỏi phải có một đội ngũ nhân lực hết sức chuyên nghiệp về ghép tạng, phẫu thuật - hồi sức tim mạch-lồng ngực, có tính tổ chức cao và tinh thông về lấy - ghép đa tạng. Cũng từ thành công của ca ghép phổi này mà đã thu được rất nhiều kinh nghiệm quí báu, nâng cao chất lượng đội ngũ cán bộ, đáp ứng tốt hơn các nhiệm vụ của bệnh viện - nhất là phát triển ghép phổi thành một phẫu thuật thường qui trong tương lai.

\section{TÀI LIÊU THAM KHẢO}

1. Dauriat $G$ et al. Lung transplantation for pulmonary langerhans' cell histiocytosis: a multicenter analysis. Transplantation, 2006; Mar 15; 81(5): 746-750.

2. Kenneth L McClain. Treatment of Langerhans cell histiocytosis. UpToDate. 12/11/2018.

3. Phạm Đức Minh, Trần Viết Tiến, Ta Bá Thắng, Đố Quyêt. Kết quả can thiệp dinh dưởng chu phâu của ca ghép phổi đầu tiên thành công tại Việt Nam. Tap chí Y - Dược học Quân sự, 2018 (4): 34-43.

4. Đồ Quyết, Tạ Bá Thắng, Đào Ngọc Bằng, Phạm Thị Kim Nhung. Kết quả điều trị và chăm sóc bênh nhân sau ghép phổi từ người cho sống đâu tiền taai Viêt Nam. Tạp chí Y - Dược học Quân sứ, 2018 (5): 71-77.

5. Nguyễn Tiến Quyết, Nguyễn Quang Nghĩa, Trịnh Hồng Sơn, Nguyễn Hữu Ước, Nguyển Quốc Kính và Cống sự. Ghép tạng tữ người cho chết não tại BV Hữu nghị Việt Đức. Ngoại khoa, 2012 (61-1,2,3): 72-79.

6. Richard D Ferguson, Craig A Holmer. Lung transplantation: therapies, complications and outcomes. Nova Science Publishers, 2011.

7. Shahid Husain et al. The 2015 International Society for Heart and Lung Transplantation Guidelines for the management of fungal infections in mechanical circulatory support and cardiothoracic organ transplant recipients: Executive summary. The Journal of Heart and Lung Transplantation, Vol 35, No 3, March 2016.

8. Ngố Đînh Trung, Nguyễn Thái Cường và Cống sự. Một số biến chứng sau ghép ở 2 bênh nhân ghép phổi từ người cho chết não tai bếnh viện Trung ương Quân đội 108. Tạp chí y dược học lâm sàng 108, 2019 (14): 75-80.

9. Nguyễn Hữu Ước, Vũ Văn Thời, Pham Tiến Quân, Vũ Văn Giáp ${ }_{h}$ Ngô Quý Châu. Vái trò nội soi phế quản sau phâu thuật ghép phổi từ người cho chết não. Tạp chí Y học lâm sàng, 2019 (109): 18-25. 